\title{
METAPLAZIA PANCREATICĂ A MUCOASEI GASTRICE LA COPIL
}

\author{
Raluca Damian', Cristina Oana Mărginean ${ }^{1,3}$, Nicoleta Suciu ${ }^{3}$, \\ Maria Oana Mărginean³, Simona Mocan ${ }^{4}$, Lorena Elena Meliț ${ }^{3,4}$ \\ ${ }^{1}$ Clinica de Neonatologie 1, Spitalul Clinic de Urgență, Târgu-Mureş \\ ${ }^{2}$ Clinica Pediatrie 1, Spitalul Clinic de Urgență, Târgu-Mureş \\ ${ }^{3}$ Universitatea de Medicină şi Farmacie, Târgu-Mureş \\ ${ }^{4}$ Departamentul de Anatomie Patologică, Spitalul Clinic de Urgență, Târgu-Mureş
}

\begin{abstract}
REZUMAT
Metaplazia pancreatică este definită drept apariția țesutului pancreatic într-o locație anormală şi fară conectare directă la pancreas. Țesutul pancreatic heterotopic este cel mai frecvent observat la nivelul mucoasei antrale gastrice, în duoden şi jejun. Prezentăm cazul unei paciente în vârstă de 13 ani care s-a internat în Clinica Pediatrie 1 Târgu-Mureş pentru dureri abdominale recurente şi pirozis. Investigațiile de laborator efectuate au evidențiat limfocitoză $(41 \%)$ cu monocitoză $(8,9 \%)$, eozinofilie $(4,9 \%)$, un număr crescut de reticulocite $(20 \%)$, un nivel seric scăzut al trigliceridelor şi o valoare peste limita superioară a calciului şi magneziului. Ecografia abdominală nu a pus în evidență modificări patologice. Endoscopia digestivă superioară a evidențiat o mucoasă gastrică granulară. Astfel, s-a prelevat un fragment de biopsie de la nivel antral, iar examenul histopatologic a evidențiat prezența unui focar de metaplazie pancreatică la nivelul mucoasei antrale gastrice. Evoluția a fost favorabilă cu dietă şi tratamentul leziunilor asociate. Particularitatea cazului constă în prezența metaplaziei pancreatice a mucoasei gastrice la o pacientă cu dureri abdominale recurente şi pirozis, fără antecedente heredo-colaterale sau personale semnificative.
\end{abstract}

Cuvinte cheie: metaplazie pancreatică, copil, dureri abdominale, pirozis

\section{INTRODUCERE}

Metaplazia pancreatică a mucoasei gastrice reprezintă procesul în care mucoasa normală a stomacului este înlocuită cu formațiuni pancreatice, care mimează structura acinilor pancreatici $(1,2)$. Metaplazia pancreatică la nivelul mucoasei gastrice a fost descrisă pentru prima dată în anul 1993, de Doglioni, iar incidența ei, în ultimii ani, este din ce în ce mai mare (3). Până în prezent, nu au putut fi descrise cu exactitate cauzele declanşatoare ale metaplaziei pancreatice de la nivelul mucoasei gastrice. Dacă la adult metaplazia mucoasei gastrice este frecvent asociată cu procese inflamatorii cronice, precum gastrite sau ulcere, în cazul copiilor, prezența metaplaziei pancreatice pare a fi cauzată de o problemă în dezvoltarea şi diferențierea mucoasei gastrice. Un alt factor declanşator al metaplaziei de la nivelul mucoasei gastrice se presupune a fi infecția şi leziunile produse de bacteria Helicobacter Pylori (4). Din punct de vedere histopatologic, meta- plazia pancreatică a mucoasei gastrice se prezintă sub forma unor focare metaplazice, localizate în treimea inferioară a corionului gastric şi care conțin celule acinare pancreatice, dispuse sub formă de cuiburi sau lobuli, cu dimensiuni variabile de până la 1,7 mm diametru. Țesutul metaplazic poate fuziona cu glandele fundice gastrice. Rar, pot să apară celule acinare izolate sau dispuse în cuiburi printre glandele fundice gastrice. Celulele pancreatice acinare au formă piramidală şi se caracterizează prin citoplasmă abundentă, acidofilă şi fin granulară în porțiunile apicale şi mijlocii, şi bazofilă în compartimentul bazal. Granulațiile sunt mici, acidofile, slab PAS-pozitive, dispuse în citoplasma medie şi apicală. Aceste granule conțin tripsină, amilază si lipază (6). Nucleii celulelor acinare pancreatice sunt mici, localizați central sau bazal şi prezintă un nucleol proeminent (3). Tabloul clinic al acestor pacienți poate include simptome frecvente, precum: epigastralgia, reflux gastro-esofagian, dureri abdominale cronice, grețuri, vărsături, hemateme- 
ză, apetit capricios cu inapetență, pierdere ponderală progresivă, sindrom anemic prin deficit de fier (4). Diagnosticul diferențial implică alte tipuri de metaplazii, precum cea intestinală. Pentru confirmarea diagnosticului, metoda de elecție este endoscopia digestivă superioară, care permite în anumite cazuri vizualizarea leziunii şi preluarea de biopsii multiple necesare pentru confirmarea obligatorie a diagnosticului histopatologic (7). Tratamentul metaplaziei pancreatice este determinat de severitatea afecțiunii. În cazurile severe, rezecția chirurgicală este singura opțiune (8).

\section{PREZENTARE DE CAZ}

Prezentăm cazul unei paciente în vârstă de 13 ani, care s-a internat în Compartimentul de Gastroenterologie al Clinicii Pediatrie 1 Târgu-Mureş, prezentând dureri abdominale recurente şi pirozis. Antecedentele heredo-colaretarale şi cele personale nu au evidențiat elemente relevante. Elementele patologice evidențiate de examenul obiectiv efectuat în momentul internării au fost următoarele: stare generală influențată, abdomen suplu, elastic, dureros la palpare în epigastru, G: $45 \mathrm{~kg}$.

Analizele de laborator efectuate nu au relevat modificări patologice semnificative sau specifice. Astfel, hemoleucograma a evidențiat limfocitoză (41\%) cu monocitoză $(8,9 \%)$ eozinofilie $(4,9 \%)$; de asemenea, s-a identificat un număr crescut de reticulocite $(20 \%)$, un nivel seric scăzut al trigliceridelor $(48,8 \mathrm{mg} / \mathrm{dl})$ şi o valoare peste limita normală a calciului $(\mathrm{Ca} 2,57 \mathrm{mmol} / \mathrm{L})$ şi a magneziului $(\mathrm{Mg} 1$ $\mathrm{mmol} / \mathrm{L}$ ), restul parametrilor fiind în limite normale, inclusiv amilaza serică. Investigațiile paraclinice, cum ar fi ecografia abdominală, nu au relevat modificări patologice vizibile. Luând în considerare simptomatologia clinică sugestivă pentru o afecțiune gastrointestinală, s-a efectuat endoscopie digestivă superioară, moment în care am observat prezența refluxului gastro-esofagian şi un aspect macroscopic granular al mucoasei gastrice şi am prelevat biopsie de la nivelul mucoasei gastrice antrale. Examenul histopatologic efectuat din piesa bioptică recoltată a evidențiat un focar de metaplazie pancreatică la nivelul mucoasei gastrice (Fig. 1 şi 2).

Astfel, a fost stabilit diagnosticul de metaplazie pacreatică la nivelul mucoasei gastrice şi a fost recomandată dietă cu evitarea alimentelor prăjite, condimentate, grăsimilor, sucurilor şi tratament medicamentos cu inhibitor de pompă protonică (Nexium $40 \mathrm{mg} / \mathrm{zi}$ ) şi prokinetic (Motilium 2x10 $\mathrm{mg} / \mathrm{zi}$ ) timp de o lună. Evoluția pacientei a fost favorabilă.
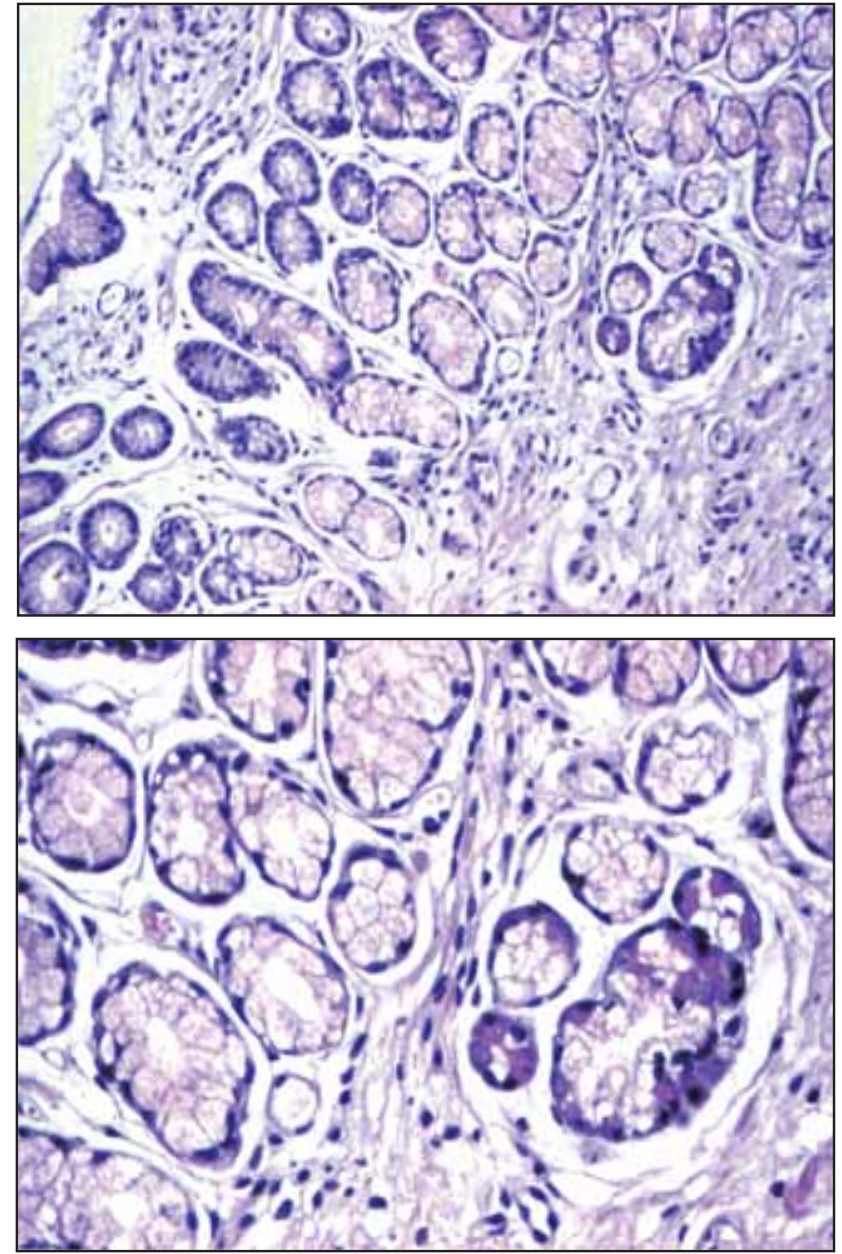

FIGURA 1 şi 2. Aspect histopatologic al metaplaziei pancreatice de la nivelul mucoasei gastrice

Particularitatea cazului constă în prezența metaplaziei pancreatice a mucoasei gastrice la o pacientă cu dureri abdominale recurente şi pirozis, fără antecedente heredo-colaterale sau personale semnificative.

\section{DISCUȚII}

Termenul de metaplazie sugerează faptul că procesul de transformare are loc în viața postnatală şi că țesutul apare într-un loc în care nu se găseşte în mod normal. Unii cercetători consideră că este un proces de adaptare a structurilor la noile condiții ale mediului înconjurător. În literatura de specialitate, tot mai des este citat faptul că acest proces de transformare apare la nivelul țesuturilor care au fost supuse unor traume cronice, infecții sau stimulări hormonale, prin urmare fiind supuse unor procese continue de regenerare $(9,10)$. Un studiu efectuat de Doglioni et al, descrie faptul că metaplazia pancreatică este prezentă în aproximativ 12\% din cazurile cu gastrită autoimună, care apare de obicei la nivelul cardiei şi coexistă cu alte tipuri de metapla- 
zie, precum cea intestinală (11). Jhala NC descrie în anul 2003, o incidență de 11\% a metaplaziei pancreatice la nivelul mucoasei oxintice, studiind fragmente de biopsie gastrică la pacienții adulti, dintre care $9 \%$ asociază gastrită autoimună, $1 \%$ prezintă gastrită atrofică cronică multifocală şi $1 \%$ prezintă mucoasă gastrică normală (5). În cazul pacientei prezentate mai sus, nu au fost identificate alte asocieri patologice ale mucoasei gastrice, restul mucosei prezentând aspect histopatologic normal. Diagnosticul de metaplazie pancreatică este dificil de stabilit, mai ales atunci când există un proces inflamator abundent, iar celulele acinare pot fi confundate cu celulele parietale din partea fundică a glandelor gastrice. În aceste situații, tehnicile imunohistochimice sunt foarte utile, aducând un avantaj considerabil, prin sublinierea prezenței enzimelor caracteristice celulelor acinare pancreatice (3). Patogeneza moleculară a metaplaziei pancreatice este insuficient cunoscută. Unii autori sunt de acord cu faptul că metaplazia pancreatică rezultă dintr-o diferențiere aberantă a celulelor stem prezente la nivelul gâtului glandelor gastrice (8). Studiul realizat de Integlia et al descrie caracteristicile clinice si patologice la 6 copii cu vârste cuprinse între 8 şi 18 ani, cu dovezi clare de metaplazie pancreatică a mucoasei gastrice. Din cei 6 copii, 2 au prezentat boală de reflux gastro-esofagian şi dureri abdominale cronice, unul a prezentat ulcer duodenal şi unul a asociat gastrită nodulară. Anemia prin deficit de fier a fost prezentă în 4 din cele 6 cazuri, iar 3 din 4 pacienți cu această constatare au prezentat şi hematemeză. Toate biopsiile efectuate au fost nega- tive pentru Helicobacter Pylori (4). În mod similar, pacienta noastră a prezentat dureri abdominale cronice și reflux gastro-esofagian, iar examenul histopatologic nu a evidențiat prezența Helicobacter pylori în fragmentul bioptic recoltat din mucoasa gastrică antrală. Johansson J et al consideră că metaplazia pancreatică de la nivelul mucoasei gastrice poate fi o leziune dependentă de vârstă, sexul feminin şi de refluxul gastro-esofagian, fiind asociată cu infecția cu Helicobacter Pylori (12,13). Metaplazia pancreatică identificată în cazul prezentat de noi apare de asemenea la sexul feminin, fiind asociată cu reflux gastro-esofagian, însă fără infecție cu Helicobacter pylori. În literatura de specialitate sunt surse care susțin că insulele de celule acinare pancreatice produc enzime pancreatice, cum ar fi amilază, lipază si tripsinogen (3). Cu toate acestea, amilazemia efectuată în cazul pacientei noastre a fost în limite normale. Etiologia metaplaziei pancreatice este încă neclară, astfel că sunt necesare studii ulterioare pentru elucidarea acesteia.

\section{CONCLUZII}

Metaplazia pancreatică însoțită de modificări ale mucoasei gastrice şi reflux gastro-esofagian a fost o descoperire endoscopică, ceea ce impune această explorare la copiii cu dureri abdominale recurente şi pirozis. Tratamentul comun al leziunilor asociate metaplaziei a ameliorat tabloul clinic. Patogenia metaplaziei pancreatice a mucoasei gastrice şi prognosticul pe termen lung sunt încă neelucidate. 